$\mathrm{SAD} / \mathrm{JSR}$

Sosyoloji Araştırmaları Dergisi / Journal of Sociological Research

Cilt / Volume 18 Sayı / Number 2 (Ekim/October 2015) : (1-17)

\title{
DEVELOPING INTERPROFESSIONAL COLLABORATIVE PRACTICE IN THE CRIMINAL JUSTICE SYSTEM IN ENGLAND AND WALES
}

\author{
Ercan BALCIOĞLU ${ }^{1}$ \\ Erkan PALA ${ }^{2}$ \\ Ali YILDIRIM ${ }^{3}$
}

\begin{abstract}
Interprofessional Collaborative Practice has proved to be an important concept in the health and social care system across the world. The Criminal Justice System in England and Wales has, over the recent years, striven to deploy the central tenets of this phenomenon in an effort to enhance service delivery but more is needed to promote partnership working. This paper addresses the fundamental benefits of Interprofessional Collaborative Practice before moving on to recommending two models that could be utilised in the criminal justice system, highlighting the areas it could potentially benefit. The paper concludes that an ineffective and inefficient criminal justice system has serious repercussions, which can only be reduced through partnership work.
\end{abstract}

Keywords: Interprofessional Collaborative Practice, Criminal Justice System, Effective Judicial System, Effective Policing, Partnership, UK.

\footnotetext{
${ }^{1}$ Yard. Doç. Dr., Kilis Üniversitesi, İktisadi İdari Bilimler Fakültesi, Siyaset Bilimi ve Kamu Yönetimi Bölümü

${ }^{2}$ Ph.D., Loughborough Üniversitesi, Sosyal Bilimler Bölümü

${ }^{3}$ Ph.D., De Montfort Üniversitesi, Dil ve Konuşma Terapisi Bölümü

$\mathrm{SAD} / \mathrm{JSR}$

Cilt / Volume 18 Sayı / Number 2 


\section{INGILTERE VE GALLER CEZA ADALET SISTEMINDE INTERPROFESYONEL İŞBİRLİĞİ UYGULAMASINI GELISSTIRMEK}

\section{ÖZET}

İnterprofesyonel İşbirliği Uygulaması, birçok ülkede sağlık ve sosyal hizmet sisteminde önemli bir kavram olarak kabul edilmektedir. Son yıllarda, İngiltere ve Galler'de devlet, Ceza Adaleti Sistemine vatandaşın güvenini artırmak ve daha hızlı, etkili ve kaliteli hizmet sunabilmek için yoğun bir çaba sarf etmektedir. Bunu sağlamak için İnterprofesyonel İşbirliği Uygulaması yaklaşımının temel prensiplerini çeşitli uygulamalarla yaygınlaştırmaya ve yerleştirmeye çabalamaktadır. Tüm çabalara rağmen hala ceza adalet profesyonelleri arasında daha fazla ortakl çalışmanın geliştirilmesi gereklidir. Bu çalışmada öncelikle, İnterprofesyonel İşbirliği Uygulamasının temel faydaları ele alınacaktır. Daha sonra İnterprofesyonel İşbirliği Uygulamasının ceza adaleti sisteminde kullanılmasının olası faydalarına değinilecektir. Son olarak da, İnterprofesyonel İşbirliği Uygulamasından ceza adaleti sisteminde nasıl yararlanılabileceğine yönelik iki model önerilecektir. Sonuç olarak, etkisiz ve verimsiz ceza adalet sisteminin telafisi mümkün olmayan mağduriyetlere yol açtığı bu mağduriyetlerin ancak ceza adalet profesyonelleri arasında meslek öncesi ve meslek sonrasında ortaklık çalışmasının geliştirilmesiyle azaltılabileceği sonucuna varılmıştır.

Anahtar Kelimeler: İnterprofesyonel İşbirliği Uygulaması, Ceza Adalet Sistemi, Etkili Hukuk Sistemi, Ortaklık, Etkili Polislik, Birleşik Krallık. 


\section{INTRODUCTION}

Interprofessional Collaborative Practice (IPCP), a model which first gained academic popularity in the health and social care sector following the advice of the Beveridge Report in 1942, occurs "when multiple health workers from different professional backgrounds work together with patients, families, carers and communities to deliver the highest quality care" (WHO, 2010:55). Shared team goals, ideas, decision making, team identity, partnership and integration of team members, have been identified as some of the key elements of IPCP (WHO, 2010). Although professionals' ideology, values, self-interest and specialisms often differ, partnership working within and between agencies has been found to be directly related to health service user satisfaction partly because professionals' enhanced relationships with each other directly influence their attitudes towards patients (Barr et al., 2010). Professionals' communication skills and knowledge around health and social care were found to be enhanced as a result of increased integration with other professionals and patients (Revees et al., 2010).

As illustrated above, IPCP has gained an important space within the health care system, largely due to its potential in delivering highest quality medical care through collaboration. Criminal justice systems across the world also strive to provide enhanced service delivery but their efforts have largely excluded the principles of IPCP: "at a national level we [the government] have too often failed to take the opportunity to collaborate" (Ministry of Justice, 2013a:34). Transforming the Criminal Justice paper in 2013 highlighted that the success in delivering shared outcomes is only possible "if all parts of the CJS [Criminal Justice System] collaborate effectively" (Ministry of Justice, 2013b:34). Before advancing any further, it is worth highlighting that similar to health and social care, criminal justice systems consist of various agencies with different areas of expertise, roles and responsibilities. The intention of the CJS is to work towards reducing crime and reoffending; increasing public confidence; 
and ensuring the system is fair and just. Responsibility for justice delivery falls mainly to the National Offender Management Service (NOMS) and Her Majesty's Courts and Tribunal Service (HMCTS). It is within the Police's remit to tackle crime and anti-social behaviour, whilst the relatively recently introduced Police and Crime Commissioners (PCCs) work to maintain efficient and effective local policing. Although health and social care's area of expertise differ dramatically to the CJS, the similarities in the way they function must not go unnoticed. For example both are outcome driven; where in the health and social care patient safety is at the forefront, victims' and offenders' rights are some of the main concerns of criminal justice systems; and where patients are actively involved in decision-making, restorative justice prevails in the criminal justice system which focuses on the needs of the victims and the offenders in the quest for justice.

\section{Developing Inter-Professional Collaborative Practice in the Criminal Justice System}

An effective criminal justice system relies on the collaboration of agencies, including the cooperation of victims, witnesses and defendants (Ministry of Justice, 2013a). Lack of partnership between the criminal justice agencies and poor coordination between partners has led to the introduction of the Criminal Justice Board (CJB) in 2013, which consists of a wide range of senior leaders across the justice system and beyond, including the Crown Prosecution Service, the Courts, the Victims' Commissioners, the National Offender Management Service and the National Crime Agency. The Board aims to ensure a 'whole system' approach to tackling evolving issues across the Criminal Justice System in England and Wales. Furthermore, the Board will:

- Address barriers which currently prevent integration;

- Develop a transparent approach to all CJS contracts in the procurement pipeline beginning with those in the Ministry of Justice, to provide new opportunities for collaboration; and 
- Draw up criteria against which all CJS contracts can be assessed with a view to identifying opportunities for cooperation between criminal justice agencies, and cost savings.

\section{Interprofessional Collaboration Boards}

The total funding of the criminal justice system by central government is around $£ 17.1$ billion a year (Morse, 2014:16). Traditionally each criminal justice system agency has had their own aims and targets to deliver services but to achieve the government's ultimate aims of reducing crime, increasing public confidence and ensuring that the criminal justice system is fair and consistent requires joint working and operations. To a large extent, all agencies depend on one other. This is particularly the case during the quest to bring individuals to justice. For example, around half of all criminal court trials do not go ahead as planned largely because the defendant offers acceptable pleas or the prosecution offers no evidence (Morse, 2014: 27). Consequences are the waste of allocated time and importantly the negative impact on public confidence in the system since witnesses have been unnecessarily inconvenienced (Office for Criminal Justice Reform, 2007:3).

The government's white paper noted the need for a strong link between the Criminal Justice Board and local criminal justice partnerships (Ministry of Justice, 2012a: 36). To build this important link, Interprofessional Collaboration Boards (IPCB) could be introduced, bringing together criminal justice agencies at the local level to address regional concerns and plan how they will deliver improvements through collaboration. Accountable to CJBs, IPCBs could oversee the functionality of a region's justice system, touching on a wide-range of issues including the causes of cracked and ineffective trials, the duration of criminal cases, identifying and sharing good practice, reviewing respective plans and concerns, analysing each other's service delivery and performance and taking into account the changing needs of the local community. 
The Criminal Justice Board could support the strategic planning and performance of IPCBs who will be striving to design and implement solutions to local-level malfunctions in the justice system through the sharing of expertise and knowledge. Lack of Interprofessional collaboration between local criminal justice agencies can lead to a slow and too bureaucratic criminal justice system (Ministry of Justice, 2013b). Criminal justice system agencies have already demonstrated that

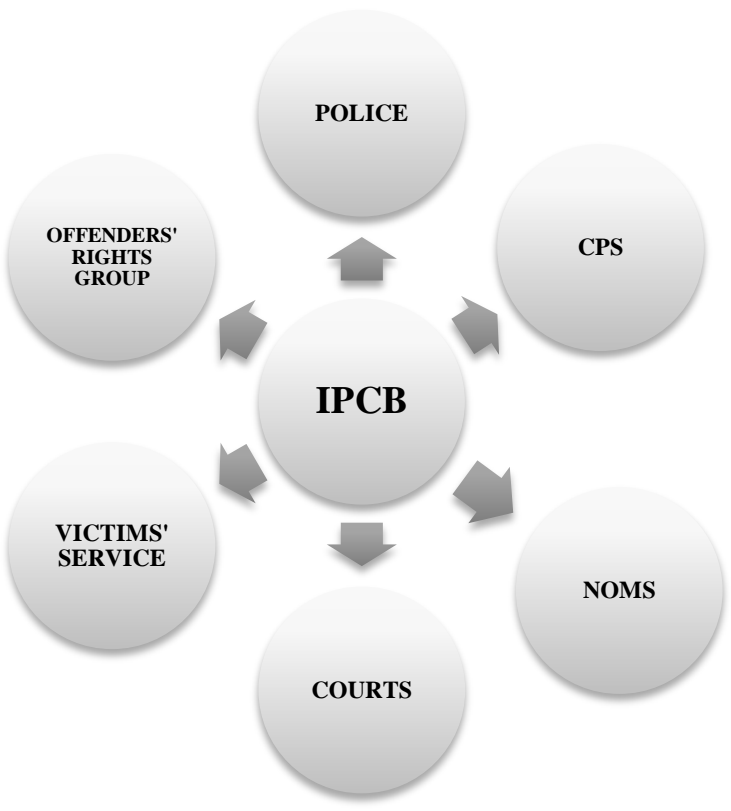

Figure 1: Interprofessional Collaboration they could work together to delivery quick and fair justice. In the 2011 London riots, for example, marked increased collaboration between local criminal justice agencies ensured that those arrested were quickly transferred from police cells to court rooms, ready to dispense justice with all necessary reports and personnel. Within a month of the riots, over 1,700 people were trialled in connection with the disturbances (Ministry of Justice, 2012b: 18). It is apparent that the criminal justice system needs to continue working this way because malfunctions which occur in criminal proceedings in one or more part of the system can slow down or completely disable other parts of the system. Frankly, for too long, the criminal justice system operated in a manner that caused problems. In 2002, approximately 9,800 defendants were convicted by magistrates' and then committed to the Crown Court for sentencing but investigating these referrals has shown that $40 \%$ were unnecessary and could have been handled in the magistrates' court. This resulted in delay and frustration for victims, witnesses and staff. Take Her Majesty's Courts and Tribunals Service (HMCTS), as another example. This particular agency handles over 2 million criminal cases (and around 2.8 million civil, tribunal and 
family law disputes) (Justice, 2014), and the 'average waiting time' (the time between the date of sending a defendant to the court and the start of hearing) for defendants who pleaded not guilty in the Crown Court was 24 weeks (171 days) in 2011(Ministry of Justice, 2012c: 5), increasing to 25.1 weeks in the fourth quarter of 2012 (Ministry of Justice, 2012d:37). The 'average waiting time' was 12 weeks when a defendant pleaded guilty in the fourth quarter of 2012 (Ministry of Justice, 2012a:5), showing no statistical change from 2011 figures (Ministry of Justice, 2012d:37). Even the most simple cases can take several months to reach a conclusion: summary motoring cases took 183 days on average, for example, in the first quarter of 2013 (Ministry of Justice, 2013c). Many defendants are thus waiting for their trial in custody, and undoubtedly some of these unconvicted prisoners will be found innocent. The impact of late justice does not only affect the defendants: other than the financial costs that are associated with lengthy criminal procedures, victims too will have to wait a lengthy time to appear at the court to give evidence against the defendant. Indeed, delays can occur in the quest for justice and these can vary between geographic regions: "the difference between the average length of proceedings in the best and worst performing areas is 3 weeks in the magistrates' courts and 10 weeks in the Crown Court" (Ministry of Justice, 2012e:15). Some variations can be expected between geographic regions but it is clear that there is potential to reduce the discrepancy between regions. IPCBs' will be working towards understanding where delays occur in proceedings, what causes them and what can be done to improve the situation. The solution to tackling delays will entail strong collaboration particularly between that region's police, prosecution service and its courts.

IPCBs could also play an important role in rehabilitating offenders and protecting the public, ultimately enhancing public confidence in the criminal justice system. Hough's et al., (2013: 30) study into public attitudes to sentencing and trust in justice has shown that only $43 \%$ of the public believe that the criminal justice system is effective, raising implications for the justice system. Although there 
have been some improvements in reoffending rates over the last few years, they remain a concern (Ministry of Justice, 2012e: 18):

"in the year to December 2011, over $75 \%$ of proven offences were committed by offenders who had a previous reprimand, warning, caution or conviction for an offence; and $47 \%$ of adult offenders, and $69 \%$ of juvenile offenders, reoffend within a year of leaving custody."

Clearly, the criminal justice system has little effect on offenders' behaviour. IPCBs, on the other hand, would ensure that local agencies are responsive and flexible in their community. Giving local criminal justice agencies the discretion to put forward proposals to test new ideas in their community through partnership work will lead to a better understanding of how reoffending can be reduced, and provide the CJBs with the data they need to consider a national-level programme of reform.

\section{Interprofessional Collaboration Teams}

Interprofessional Collaboration Teams (IPCTs) aim to change the culture and approach to criminal proceedings in the criminal justice system. Offenders', victims' and witnesses' interests will be the primary concern of IPCTs. Overseen by the IPCB, it will be within this team's remit to provide a preliminary decision for each crime case in a reliable and effective fashion, ready for the consideration of the judge/magistrate if no pleas are made.

Last year's Swift and Sure Justice white paper noted that 'local professionals are best placed to decide how to deal with crime and anti-social behaviour in their communities' (Ministry of Justice, 2012e: 37) but there does not exist any platform where all local criminal justice boards can collaborate. Facilitating

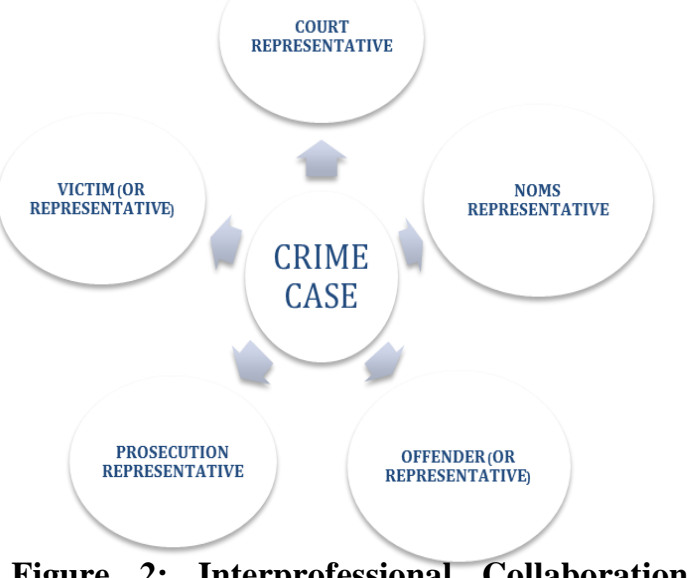


communication between local criminal justice agencies prior to case conclusion could be the biggest change in culture and approach to criminal proceedings. Such meetings will encourage parties to be more open and creative in finding a mutually agreed solution before the trial date. To date, for example, the NOMS has had very little to say about potential clients: these meetings could be taken as an opportunity to inform other partners about the likelihood of successful integration back into the society based on the offender's background, potential effects of imprisonment on the offender and the wider society. Providing NOMS with the opportunity to express their concerns for each potential client, could, furthermore, play a part in preventing unsuitable clients falling into the hands of NOMS. The elderly, young people and drug addicts are some of the controversial clients of the NOMs. Other controversial service users are the mentally ill. The scale of the mentally ill among the prison population in England and Wales has been considerable for numerous decades. The Mental Health Foundation, for example, highlighted that one in five prisoners has four major mental health disorders (Mental Health Foundation, 2007:30); and between March 2013 to March 2014 the number of suicides increased by almost $70 \%$ at the same time as prison staff were cut by roughly $30 \%$ (Ministry of Justice, 2014:8). Mental disorders were one of the main reasons behind deaths in custody in 2014: between January and May 2014, there were 68 deaths in custody and 32 of these were self-inflicted (Howard League for Penal Reform, 2014).

As well as the NOMS, IPCTs will offer victims and offenders the opportunity to express their feelings in the resolution of offences, to the concept of 'restorative justice'. Offenders will be made aware of the consequences of their actions on victims and the impact that it has had upon the police and the wider society. A reduction of an approximate $14 \%$ reduction was found in the number of offenders reoffending who had participated in restorative justice, and $85 \%$ of victims who participated in the programme were satisfied with their experience (Ministry of Justice, 2012a:3). 
There are two basic requirements that must be met for victims' and offenders' direct involvement in these meetings: the offender must accept responsibility for the crime and both the victim and the offender must be willing to participate. In cases where the victim or offender refuses to participate, their representatives will be invited to these meetings to facilitate communication with other members of the team: the police, prosecution, corrections units and courts.

Numerous recommendations have been made to cut the cost of dispensing justice, ranging from increasing magistrates' powers to the digitalisation of agencies, meaning information could be shared electronically across criminal justice system agencies. The cost that is associated with failed cases totalled over £25million in 2011/12 alone (representing 4.3\% of the CPS's net operating cost) (Policy Exchange, 2012:34), wasting the resources of not only the CPS but also Her Majesty's Courts and Tribunal Services (crucial judiciary time wasted as well as the physiological impact on witnesses and victims) and the police system (time devoted to investigation and submission of evidence). In May 2013 for example, a kidnap trial dropped because disclosure was inadequate, leading to a $£ 500,000$ costs order against the CPS (Guardian, 2013) at a time when the organisation is necessitated to cut its expenditure by $25 \%$ over a four year period. Staff numbers have reduced and will continue to reduce, inevitably affecting the CPS's ability to be 'fair and consistent' in their decisions to prosecute. Moreover, the Howard League for Penal Reform (2014a) said the courts in the United Kingdom (UK) spends approximately $£ 429$ million a year on imprisoning individuals on remand, and $£ 230$ million of this figure is "wasted" on 3,500 individuals who were later acquitted or given a non-custodial sentence. Richard Monkhouse, the deputy chairman of the Magistrates' Association, suggested the increased use of magistrates' courts which are cheaper to run that crown courts. This is a valid recommendation at a glance when one considers that a hearing in a crown court costs on average 
$£ 3,900$ in contrast to $£ 900$ in a magistrate's court. The discrepancy between the two is even bigger if the defendant pleads guilty (The Economist, 2013).

Enhanced engagement between the CPS and defense can lead to a faster and less erratic system (Ministry of Justice, 2013d: 14), and the creation of IPCTs will facilitate this. Through these meetings not only will guilty pleas be identified earlier and more trials will be conducted on the planned day but the reliability of cases passed on to courts will be further enhanced. These meetings can assist in clarifying issues, enabling the actual trial to be more focused, error free and less contentious. In 2011/12 alone, $86.7 \%$ of cases trialled in the Magistrates' Court and $80.8 \%$ of cases in the Crown Court led to a conviction (Policy Exchange, 2012:27). The initial reaction to these figures may well be positive but these conviction rates give no strong evidence of professionalism when guilty pleas are excluded from the calculation: including guilty pleas when assessing the CPS's performance can be misleading because numerous factors can lead to a defendant pleading guilty. For example, individuals may enter a plea bargain simply to avoid the risk of being wrongly found guilty at trial. When guilty pleas are excluded, the conviction rate in the Magistrates' Court drops to only $60.7 \%$ and $30.5 \%$ in the Crown Court (Policy Exchange, 2012:30). A third of cases in the Magistrates and one in eight cases in the Crown Court were dropped because the prosecution offered no or inappropriate evidence. This suggests two things: lack of engagement between the CPS and defence and the prosecutors' strong inclination to prosecute despite being established to be independently responsible for the preparation of 'fair' cases. A member, delegate or an officer of a court could review the evidence at the IPCT meetings and comment on it before the trial. This would lead to the reduction of unsuitable evidence in trials.

A report outlining the issues raised in IPCT meetings could be submitted to the sentencing judge or magistrates for consideration. This report will be more insightful than the traditional pre-sentence 
reports since it will contain information from victims, offenders, police, prosecution and corrections services. The recommendation in the report could lead to fairer and more reliable justice, especially in magistrates' courts. The vast majority of criminal cases are already dealt with in Magistrates' Courts (95\%) by either justices of the peace (magistrate or lay magistrate) or district judges. The latter members of the judiciary have 7 years legal qualification and are full-time whereas the former members of the same judiciary are unpaid volunteers with no legally required qualification. Although they both carry out the same jobs evidence suggests that there are variations in their decisions. For example, a study commissioned by the Ministry of Justice (2011:55) stated that:

A custodial sentence was more likely to be given in a case heard by a District Judge (7\%) than by magistrates (4\%), although still in a small minority of cases;

District Judges were more likely to use conditional bail or unconditional bail (both 12\%) than magistrates ( $8 \%$ and $9 \%$ respectively);

A financial penalty was more likely to be used by magistrates (37\%) than by District Judges $(29 \%)$

Magistrates more frequently utilised endorsements/penalty points; $9 \%$ of magistrates did so compared with 6\% of District Judge cases. 


\section{DISCUSSION}

There are many reasons why the government can be proud of the criminal justice system in England and Wales. It is well reputed, admired and imitated by developing countries across the world but this does not hide its punitiveness. The number of offenders coming into contact with the NOMS has expanded over recent years, reaching 260 thousand offenders each year (Justice Gov., 2014). As of July 2014 , there were 85,428 prisoners (adult and children) of which 3,936 were female and 1,105 were children (Howard League for Penal Reform, 2014). Today there are approximately 9,500 prisoners held in prisons' Certified Normal Accommodation level, the prison service's own measure of how many prisoners can be held in good and decent standard of accommodation. Where the current cost per offender supervised on licence after custody is $£ 2.620$ (Ministry of Justice, 2013d:2), the average cost per prisoner is $£ 26,139$ per year (Ministry of Justice, 2013b: 3 ), increasing to $£ 84,158$ for male 15-17 year olds kept in Young Offender Institutions (YOI).

Other than failing to make the best use of its resources, it is often argued that the system is cumbersome and affected by unacceptable delays, causing anxiety to victims as well as increasing the financial burden on the system. The next big change must now shift from prison being the main source of stability and security to local prioritisation setting which takes account of victims, offenders, witnesses and financial pressures. Victims, offenders and even some criminal justice agencies often complain that their concerns are overlooked when important decisions are taken. In this era of austerity, effectiveness and efficiency will be at the heart of IPCBs and IPCTs, whether in terms of reducing recidivism or improving victims', witnesses' and offenders' experience.

The recommendations suggested here may seem too great, the leap too large to make but the arguments for more partnership between criminal agencies have already started to gain prominence. Not many now defend the centralised criminal justice system: " the system is in need of 
modernisation, with old fashioned and outdated infrastructures and way of working that suit the system rather than the public it serves" (Ministry of Justice, 2012e: 5). If the criminal justice system is to achieve its aims and objectives, serious deliberation, study and debate must focus on partnerships between local criminal justice agencies to meet the changing needs and expectations of the local community. 


\section{ÖZET}

İçgüvenlik kurumları, savcıllk, mahkemeler ve 1slah kurumları gibi dört temel bileşenden oluşan ceza adalet kurumlarında birçok uzmanlık alanında yüzlerce profesyonel çok sayıda iş ve işlemi ekip anlayışıyla eşgüdüm ve işbirliği içinde etkili ve hızlı bir şekilde yürütmek zorundadır. Ne var ki böylesine bir yaklaşımın uygulama boyutunun çoğu zaman sekteye uğradığını görmekteyiz. Gerek ceza adalet sistemini oluşturan kurumlar içinde yürütülen iş ve işlemlerde, gerekse ceza adalet kurumları arasında çalışma ortaklığını geliştirmek; toplumda suçu azaltmanın, huzur ve güvenliği sağlamanın, hukuk sistemine olan kamu güvenini artırmanın ve adaleti sağlamanın en etkili yollarından biri olarak ileri sürülmektedir. Ceza adalet kurumları arasında çalışma ortaklığının olmaması, suçların mahkemede kovuşturulma sürecini ve adaletin gerçekleşmesini engelleyebilmekte, ayrıca soruşturma ve kovuşturmanın her aşamasında feci sonuçlara yol açabilmektedir. Bu makalede, içgüvenlik kurumları, savcılık, mahkemeler ve 1slah kurumları gibi ceza adalet kurumlarının hem iç işleyişinde hem de birbiri arasındaki iş ve işlemlerinde makro ve mikro düzeyde daha hızlı, düzenli, etkili ve tutarlı bir adalet ve güvenlik hizmeti sunabilmek için İnterprofesyonel İşbirliği Kurullarının (İK-Interprofessional Collaboration Boards) ve İnterprofesyonel İşbirliği Takımlarının (İ̈TInteprofessional Collaboration Teams) kurulması ve güçlendirilmesi önerilmektedir. 


\section{REFERENCES}

Barr H., Freeth D., Hammick M., Koppel I. and Reeves S. (2010). Evaluations of Interprofessional Education United Kingdom Review for Health and Social Care. London: CAIPE.

Guardian. (2013). CPS Severely Hampered by Lack of Resources, Says Report. 10 July 2013, London: Guardian News and Media.

Hough M., Bradford, B., Jackson, J. and Roberts, J. V. (2013). Attitudes to Sentencing and Trust in Justice Exploring Trends from the Crime Survey for England and Wales, Ministry of Justice

Howard League for Penal Reform. (2014a). Revealed: The Wasted Millions Spent on Needless Remand. London: Howard League for Penal Reform.

Howard League for Penal Reform. (2014b). Weekly Prison Watch. London: Howard League for Penal Reform.

Justice. (2014). HM Courts and Tribunals Service. London: Ministry of Justice.

Justice Gov. (2014). About the National Offender Management Service. London: Ministry of Justice.

Ministry of Justice. (2011). The Strengths and Skills of the Judiciary in the Magistrates' Courts, Ipsos MORI- Ministry Of Justice Research Series 9/11. Ministry of Justice: London.

Ministry of Justice. (2012a). Provisional Statistics on the Timeliness of Criminal Court Cases. Ministry of Justice: London.

Ministry of justice. (2012b). Restorative Justice Action Plan for the Criminal Justice System. Ministry of Justice: London.

Ministry of Justice. (2012c). Provisional Statistics on the Timeliness of Criminal Court Cases. Ministry of Justice: London.

Ministry of Justice. (2012d). Court Statistics Quarterly October to December 2012 Ministry of Justice. Ministry of Justice: London.

Ministry of Justice. (2012e). Swift and Sure Justice: The Government's Plans for Reform of the Criminal Justice System. Ministry of Justice: London. 
Ministry of Justice. (2013a: 14). Transforming the CJS: A Strategy and Action Plan to Reform the Criminal Justice System. Ministry of Justice: London.

Ministry of Justice. (2013b). Costs Per Place and Costs Per Prisoner, National Offender Management Service Annual Report and Accounts 2012-13 Management Information Addendum. Ministry of Justice: London.

Ministry of Justice. (2013c). Probation Trust Unit Costs, Financial Year 2012-13. Ministry of Justice: London.

Ministry of Justice. (2013d). Court Statistics Quarterly January to March 2013. Ministry of Justice: London.

Ministry of Justice. (2014). Safety in Custody Statistics England and Wales Update to March 2014. Ministry of Justice: London.

Morse, A. (2014). The Criminal Justice System: Landscape Review. London: National Audit Office \& the House of Commons.

Office for Criminal Justice Reform. (2007). Joint Effective, Cracked, Ineffective and Vacated Trials in the Crown Court and the Magistrates' Courts. London: HMCS\&CPS.

Policy Exchange. (2012). The Public Interest: Reforming the Crown Prosecution Service. London: Policy Exchange.

Reeves S., Lewin S., Espin S. and Zwarenstein M., (2010). Interprofessional Teamwork for Health and Social Care. London: Blackwell-Wiley.

The Economist. (2013). What price justice?. Jun 29th 2013, London: The Economist Newspaper Ltd.

WHO. (2010). Health Professions Networks Nursing \& Midwifery Human Resources for Health Framework for Action on Interprofessional Education \& Collaborative Practice. Geneva, Switzerland: WHO Press. 